\title{
POSSIBILITIES FOR AIR FIREABLE BASE METAL CONDUCTORS
}

\author{
S. J. STEIN, C. HUANG and L. CANG \\ Electro-Science Laboratories, Inc., Pennsauken, N.J. 08110
}

\begin{abstract}
This paper discusses the status of thick conductive films formed by firing in air. The metals under study include nickel, chromium, aluminum and copper. The properties of the films are presented for firing temperatures ranging from 580 to 850 degrees $\mathrm{C}$. Compatibility with various dielectrics and glasses have been studied. Multilayer wiring seems promising. Potential uses on porcelain enamelled steel, window glass and alumina substrates seem feasible.

Initial studies have been made of compatibility with thick film ruthenium-based resistors. Some preliminary information on termination resistance and other properties observed in such combinations is presented.

Possible applications in gas discharge displays for cathodes and conductor runs are discussed. Potential uses may include economical ground planes, solar cell electrodes, varistor and thermistor terminations, and resistance thermometers.
\end{abstract}

\section{INTRODUCTION}

Everyone is aware of the upward price movements of precious metals during the past few years. These price increases have accelerated sharply, especially within the last 2 years. This has resulted in intensive pressures being applied upon users and suppliers to replace these noble metals with lower cost alternatives. Possibilities being studied include process changes, product redesign or replacement by base metals. Additionally, attempts are being made to reduce the amounts of precious metals used where they cannot be totally eliminated.

Silver, gold and the platinum group metals have extraordinary chemical and physical properties. Their reliability, durability and resistance to corrosion, over a wide temperature range, are outstanding. This has contributed to the ease in joining, contacting and wire bonding to them. Most noble metals form ohmic contacts readily and tend to retain such ohmic behavior under severe humidity, high electrical loading, and during processing to almost $1000^{\circ} \mathrm{C}$.

Many of these characteristics are not exhibited by the large number of other metals we know. Oxidation (often at room temperature), corrosion, attack by water and other chemical reagents, occurs far more readily with iron, nickel, aluminum, copper, etc.

In the case of thick film compositions, heating such base metal powders mixed with glasses to elevated temperatures in air will usually hopelessly oxidize these metals and cause them to react with the glasses and fluxes present. They will also exhibit erratic contact and joining behavior.

Thus, the early cermet work on base metal conductive cermets was limited to hydrogen (reducing), and nitrogen (inert) atmospheres. Good as-fired properties for copper and nickel have been obtained in such atmospheres, and compatible dielectrics are also available. Nitrogen fireable resistors, on the other hand, have decided performance and stability shortcomings. Much more improvement work is required before such resistors can be reliably and widely used in the thick film hybrid electronics field.

The ideal situation would be to be able to fire inexpensive conductors in air, and retain the compatible use of most of the other materials and processes currently employed. Air-fireable ruthenium-based resistors have not increased in price significantly for many years. Many variations with good properties are readily available for firing at various temperatures between $600^{\circ} \mathrm{C}$ to $1000^{\circ} \mathrm{C}$. The same good economical supply situation is true for dielectrics and glazes. Thus, the major need is for reducing the amounts or percentages of $\mathrm{Au}, \mathrm{Ag}, \mathrm{Pt}$ and Pd used in hybrid circuits. Ideally, this should be accomplished by means of air-fireable, lower cost conductors. Part of this objective has been achieved by switching from gold and platinum to high silver content $\mathrm{Pd} / \mathrm{Ag}$ conductors. However, this paper will discuss some of our efforts in utilizing copper, nickel, aluminum and chromium in air-firing compositions.

A large number of metal powder preparations have 
been made with varying degrees of success in passivation for high temperature exposure. The availability of good thick film resistors and dielectrics for use in the $580-650^{\circ} \mathrm{C}$ range has made it feasible to consider several metal conductors including copper, aluminum, chromium and nickel. These have been formulated into developmental conductor compositions, and their firing and other characteristics are presented below:

\section{EXPERIMENTAL RESULTS}

\subsection{Substrate Effects}

The four base metal conductors were fired on soda-lime glass, porcelain enamelled steel, 96\% alumina, and single crystal silicon wafer substrates. Table I lists the resistivities obtained when fired at $625^{\circ} \mathrm{C}$ in a 45 minute firing cycle with 10 minutes at peak temperature. The aluminum and chromium gave their lowest resistivities on silicon. On the other hand, the $\mathrm{Cu}$ and $\mathrm{Ni}$ are lowest on glass and enamelled steel substrates with this firing cycle.

\subsection{Effects of Firing Temperature}

Figure 1 shows the variation in sheet resistivity as a function of firing temperature on $96 \%$ alumina substrates. Belt furnace firing cycles of 45 minutes with 10 minutes at peak temperature have been used.

Nickel, \#2554, dropped in resistivity from 70 to 35 milliohms per square (mohms/sq.) as the peak temperature was increased from about $580^{\circ} \mathrm{C}$ to $930^{\circ} \mathrm{C}$.

Aluminum, \#2590, started with a higher resistivity of $250 \mathrm{mohms} / \mathrm{sq}$. at $580^{\circ} \mathrm{C}$. This dropped sharply to $15 \mathrm{mohms} / \mathrm{sq}$. by about $700^{\circ} \mathrm{C}$. Beyond that temperature, resistivity climbed rapidly reaching about $1 \mathrm{ohm} / \mathrm{sq}$. at $930^{\circ} \mathrm{C}$. Upon physical examination, tiny molten droplets of aluminum could be seen on the substrates for firing temperatures significantly above

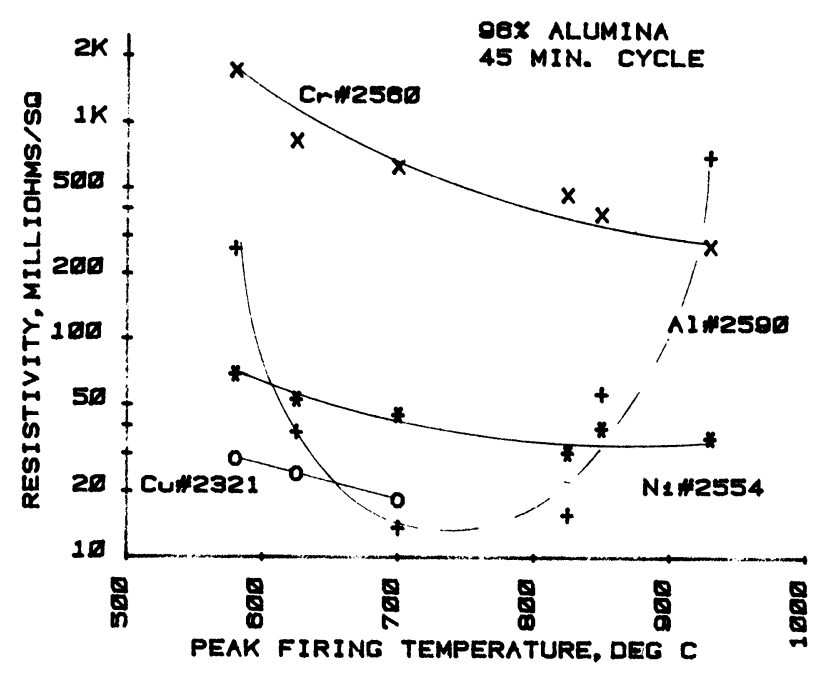

FIGURE 1 Resistivity $v s$. firing temperature.

$660^{\circ} \mathrm{C}$ (the melting point of aluminum.) The aluminum should not be fired in excess of $650-700^{\circ} \mathrm{C}$ for most applications.

Copper, \#2321, varies in resistivity from 28 to 18 mohms/sq. between 580 and $700^{\circ} \mathrm{C}$ firing. Above $700^{\circ} \mathrm{C}$, increasingly severe oxidation is noticeable. Thus, the copper should not be used at the higher temperatures.

Chromium, \#2560, exhibits a far higher resistivity than the other three conductors. As temperatures increase from 580 to $930^{\circ} \mathrm{C}$, its resistivity will decrease from about $1 \mathrm{ohm} / \mathrm{sq}$. to $300 \mathrm{mohms} / \mathrm{sq}$.

The fired samples of $\mathrm{Ni}$ and $\mathrm{Cr}$ showed no noticeable signs of oxidation in their physical appearance.

\subsection{Effect of Firing Time}

Figure 2 presents the data obtained at a constant peak firing temperature of $580^{\circ} \mathrm{C}$. The substrate is a soda-lime glass. Belt speed was varied to give total firing times ranging from 25 to 140 minutes.

TABLE I

The effect of various substrates on resistivity (milliohm/square). Peak firing temperature $-625^{\circ} \mathrm{C}$; cycle time -45 minutes.

\begin{tabular}{lclll}
\hline & \multicolumn{4}{c}{ Conductor } \\
\cline { 2 - 5 } Substrate & $\mathrm{A1} \mathrm{\# 2590}$ & $\mathrm{Cr} \mathrm{\# 2560}$ & $\mathrm{Cu} \# 2321$ & $\mathrm{Ni} \mathrm{\# 2554}$ \\
\hline Soda-lime glass & 37.5 & 766 & 15.2 & 46.2 \\
Porcelain enamelled steel & 125.0 & 646 & 14.4 & 45.0 \\
96\% $\mathrm{Al}_{2} \mathrm{O}_{3}$ & 37.8 & 829 & 23.9 & 53.2 \\
Silicon wafer & 11.2 & 430 & 24.5 & 59.0 \\
\hline
\end{tabular}




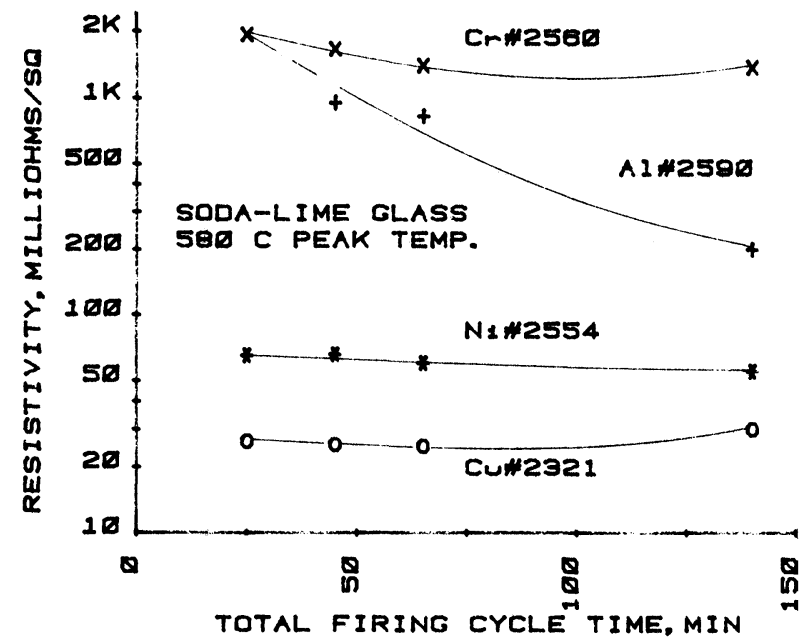

FIGURE 2 Resistivity $v s$. firing cycle time.

Interestingly, both the nickel and copper resistivities seem fairly independent of time at this temperature. $\mathrm{Cr}$ shows a moderate drop in resistivity with increasing time. On the other hand, the $\mathrm{Al}$ drops more than 1 decade as the time at peak increases over 5 fold. It is obvious that insufficient densification and sintering occur at $580^{\circ} \mathrm{C}$ for aluminum. By comparing Figures 1 and 2 , the aluminum would achieve much better conductivity more quickly, if the firing temperature is raised to the 650-700 region.

\subsection{Multiple Refiring Effects}

Figure 3 shows the effects of refiring these conductors for up to 10 firing cycles. The peak temperature used is

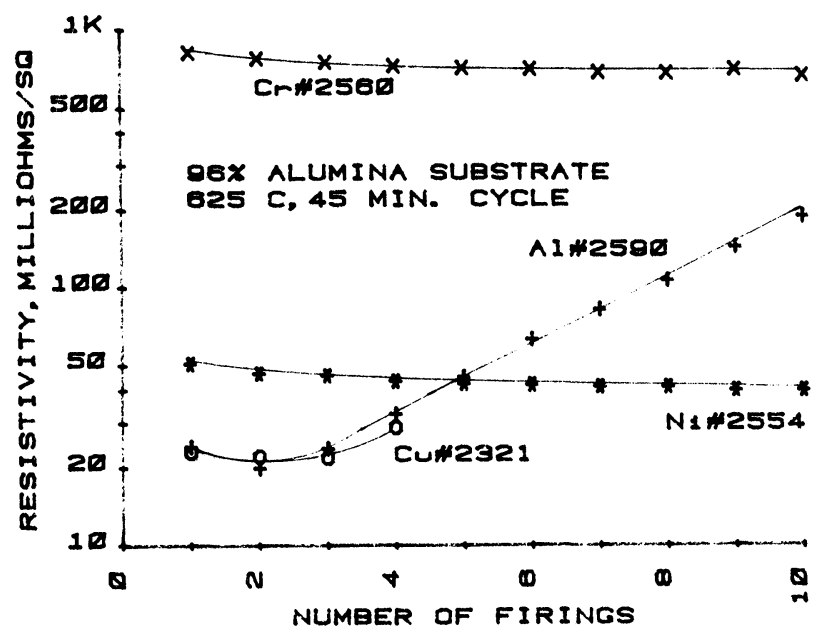

FIGURE 3 Resistivity $v s$. number of refines. $625^{\circ} \mathrm{C}$ on $96 \%$ alumina substrates. The $\mathrm{Ni}$ and $\mathrm{Cr}$ conductors are apparently stable and show slightly improved conductivity after 10 refiring cycles.

However, the $\mathrm{Cu}$ and $\mathrm{Al}$ are only able to withstand 2 or 3 refires at these conditions before undergoing rapid oxidation. Copper in particular became non-conductive after 5 refires. The aluminum resistivity continues to rise with each refire, but has not completely "run away" even after 10 firings.

\subsection{Dielectric Compatibility}

Simple crossover and capacitor test patterns have been made using black dielectric \#M-4023B. Each of the 4 conductors tested was printed as the bottom electrode and dried. Two layers of the dielectric were then printed and dried. After the top electrode of the same metal was printed, the four layers were all cofired at $580^{\circ} \mathrm{C}$. Table II lists the results.

The $\mathrm{Ni}, \mathrm{Cr}$ and $\mathrm{Cu}$ all give satisfactory low picofarad capacitance. The $\mathrm{Al}$ gives no measurable capacitance, indicating chemical incompatibility. Application of $\mathrm{Ni}$ conductors with \#M-4023B in multilayer circuits used in DC gas discharge displays is feasible. Several other nickel variations are available for study in applications such as cathodes, and glass seal feed-through conductors.

Several other thick film multilayer dielectrics (including ESL \#M-4030) are under study for use with these conductors at different temperatures. ESL silvers \#590 and \#595 may also be used as the top conductor layer in combination with a 2,3 , or 4 level $\mathrm{Ni}$ multiconductor structure, whenever silver's unique properties are needed. This allows significant reduction of the amount of silver used in a multilayer and avoids dangers of shorting through layers. We have been successful in preparing $\mathrm{Ni}, \mathrm{Cu}$ and $\mathrm{Cr}$ simple multilayers, and also capacitor patterns using \#M-4030 dielectric fired at $625^{\circ} \mathrm{C}$.

TABLE II

Compatibility with \#M-4023B dielectric. All cofired at $580^{\circ} \mathrm{C}$ for $45 \mathrm{~min}$. cycle, dried between each layer

\begin{tabular}{lrllll}
\hline & \multicolumn{2}{c}{$\begin{array}{c}\text { Capacitor size } \\
5 \mathrm{~mm} \times 5 \mathrm{~mm}\end{array}$} & & \multicolumn{2}{c}{$\begin{array}{l}\text { Capacitor size } \\
2 \mathrm{~mm} \times 2 \mathrm{~mm}\end{array}$} \\
\cline { 2 - 3 } \cline { 5 - 6 } & $\mathrm{K}$ & D.F.(\%) & & $\mathrm{K}$ & D.F.(\%) \\
\cline { 2 - 3 } $\mathrm{Ni} \mathrm{\# 2554}$ & 11.5 & 0.57 & & 13.2 & 0 \\
$\mathrm{Cr} \# 2560$ & 9.3 & 0.48 & & 11.0 & 0 \\
$\mathrm{Cu} \mathrm{\# 2321}$ & 11.5 & 0.20 & & 13.0 & 0 \\
\hline
\end{tabular}




\subsection{Electrical and Adhesion Properties}

The base metal conductors cannot be directly soldered or wire bonded. These serious short-comings can be overcome by utilizing intermediate metal layers. If ESL \#9901, silver, pads are printed on top of dried prints of the $\mathrm{Al}, \mathrm{Cr}$ or $\mathrm{Ni}$ and then cofired at $625^{\circ} \mathrm{C}$, compatible films are formed. These composite overprinted films allow soldering as well as $\mathrm{Al}$ and $\mathrm{Au}$ wire bonding on the Ag surface. The developmental copper composition reacts with many of the silver and $\mathrm{Pd} / \mathrm{Ag}$ top prints thus far tried, preventing adhesion and bonding studies from progressing further at this time. ESL gold, \#8831A, can be overprinted or overlapped with the copper without noticeable interaction.

An electroless copper solution has been found to immersion coat the \#2554, nickel, in 30 seconds. After rinsing the copper plated nickel, excellent solderability is obtained. Similar experiments with immersion tin plating of copper offer some promise of success. This work is still in progress.

Table III compares the adhesion and bonding properties of these conductors. In addition, water drop migration tests at 30 volts DC across a $2 \mathrm{~mm}$ gap are listed. \#2554 Ni, \#2590 Al, \#2560 Cr, \#2321 Cu, do not migrate under these conditions. The temperature coefficients of these base metals are highly positive. The nickel in particular has a TCR of close to $5000 \mathrm{ppm} /{ }^{\circ} \mathrm{C}$. This suggests the possibility of using it for economical resistance thermometry. It would not be as stable as platinum is for that purpose. The relatively high resistivity of the chromium plus its high temperature stability suggests its possible use in heating element applications. In fact, several of the other metals offer similar possibilities for automotive applications.

For certain applications in severe environments, these conductors may be protected with glass coatings (overglazes) similar to \#M-4030 dielectric.

\subsection{Heaters on Glass Substrates}

Ag coatings are used as the defroster heating elements on rear windows. A parallel line array of 100 square long conductive tracks between 2 bus bars was printed on soda-lime glass. ESL \# 590-C, Ag, and various base metals were compared using the pattern shown in Figure 4. The resistivity of the different conductors is shown in Table IV for firing temperatures of $625^{\circ} \mathrm{C}$ and $700^{\circ} \mathrm{C}$.

Fine thermocouples were used to measure the glass surface temperatures between heater lines. Figures 5 and 6 are plots of applied voltage versus temperature reached in 10 minutes at each voltage. Because of its lower resistivity, a silver coated plate will reach a given

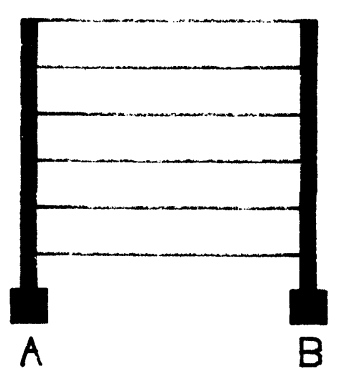

FIGURE 4 Defroster test pattern.

TABLE III

Typical properties of air fireable base metal conductors $625^{\circ} \mathrm{C} 45$ minutes cycle $-96 \% \mathrm{Al}_{2} \mathrm{O}_{3}$ substrate

\begin{tabular}{|c|c|c|c|c|}
\hline & $\# 2254, \mathrm{Ni}$ & $\# 2590, \mathrm{Al}$ & $\# 2560, \mathrm{Cr}$ & $\# 2321, \mathrm{Cu}$ \\
\hline Resistivity $(\Omega / \square)$ & 0.055 & 0.040 & 0.900 & 0.024 \\
\hline $\begin{array}{l}\text { Adhesion }(5 \mathrm{~mm} \times 5 \mathrm{~mm}) \\
\# 9901 \mathrm{Ag} \text { overprint \& cofired } \\
90^{\circ} \text { peel test }\end{array}$ & $2.5 \mathrm{Kg}$ & $1.2 \mathrm{Kg}$ & $5 \mathrm{Kg}$ & - \\
\hline $\begin{array}{l}\text { Migration test }{ }^{\mathrm{a}} \\
2 \mathrm{~mm} \text { gap, } 30 \text { volts }\end{array}$ & $>20 \min$ & $>20 \mathrm{~min}$ & $>20 \mathrm{~min}$ & $>20 \min$ \\
\hline $\begin{array}{c}\mathrm{TCR}\left( \pm 200 \mathrm{ppm} /{ }^{\circ} \mathrm{C}\right) \\
25^{\circ} \mathrm{C} \text { to } 125^{\circ} \mathrm{C}\end{array}$ & +4800 & +3000 & +1300 & +3300 \\
\hline \multicolumn{5}{|l|}{ Wire bonding } \\
\hline $\begin{array}{l}\text { \#9901 Ag overprint \& confired } \\
\text { 1. Ultrasonic Al wire } \\
\text { (1\% Si) } 25 \text { micron diameter, grams }\end{array}$ & $5-7$ & $6-8$ & $5-7$ & - \\
\hline $\begin{array}{l}\text { 2. Thermosonic } \mathrm{Au} \text { wire } 25 \text { micron } \\
\text { diameter, grams }\end{array}$ & $5-6$ & $7-9$ & $5-6$ & - \\
\hline
\end{tabular}

aMigration test is performed by applying a $30 \mathrm{VDC}$ across a $2 \mathrm{~mm}$ gap pattern with a drop of deionized water in the gap. This test pattern is monitored with an ammeter. The time required to reach 1 milliamp is recorded. 
TABLE IV

Resistance between $\mathrm{A}$ and $\mathrm{B}$ in defroster test pattern.

\begin{tabular}{lcr}
\hline & \multicolumn{2}{c}{ Firing temperature, ${ }^{\circ} \mathrm{C}$} \\
\cline { 2 - 3 } & \multicolumn{1}{c}{625} & 700 \\
\hline$\# 590-\mathrm{C} \mathrm{Ag}$ & $0.073 \Omega$ & $0.045 \Omega$ \\
$\# 2554 \mathrm{Ni}$ & $1.060 \Omega$ & $0.477 \Omega$ \\
$\# 2590 \mathrm{Al}$ & $4.600 \Omega$ & $0.152 \Omega$ \\
$\# 2560 \mathrm{Cr}$ & $26.000 \Omega$ & $14.800 \Omega$ \\
$\# 2321 \mathrm{Cu}$ & - & $0.312 \Omega$ \\
\hline
\end{tabular}

temperature, e.g., $50^{\circ} \mathrm{C}$, at lower voltages. For the $625^{\circ} \mathrm{C}$ firing, $50^{\circ} \mathrm{C}$ is reached at 0.5 volt for $\mathrm{Ag}, 1.3$ volts for $\mathrm{Ni}$, and 2.4 volts for $\mathrm{Al}$. After firing at $700^{\circ} \mathrm{C}$, the $\mathrm{Al}$ drops sharply in resistivity and becomes much closer in characteristics to silver for use in such a defroster. Data are also presented on glass failure by cracking in Figure 6. It appears that heaters on glass using $\mathrm{Al}$ or $\mathrm{Cu}$ conductive tracks might be able to withstand hot spot temperatures of $250^{\circ} \mathrm{C}$ or more. The same glass plates using $\mathrm{Ag}$ heaters seem to be limited to about a $150^{\circ} \mathrm{C}$ maximum temperature. This problem is, of course, related to the wattage or power density and thermal gradients achieved in each case.

The base metal conductors offer promise as defroster elements on glass for automotive windows, refrigerator doors, and other uses on many different substrates. Some rearrangement of the heater geometry to compensate for the different resistivities and the low voltages available would be required. Ag overlayer sol. . ring pads could be cofired at contact points corresponding to A and B in Figure 4.

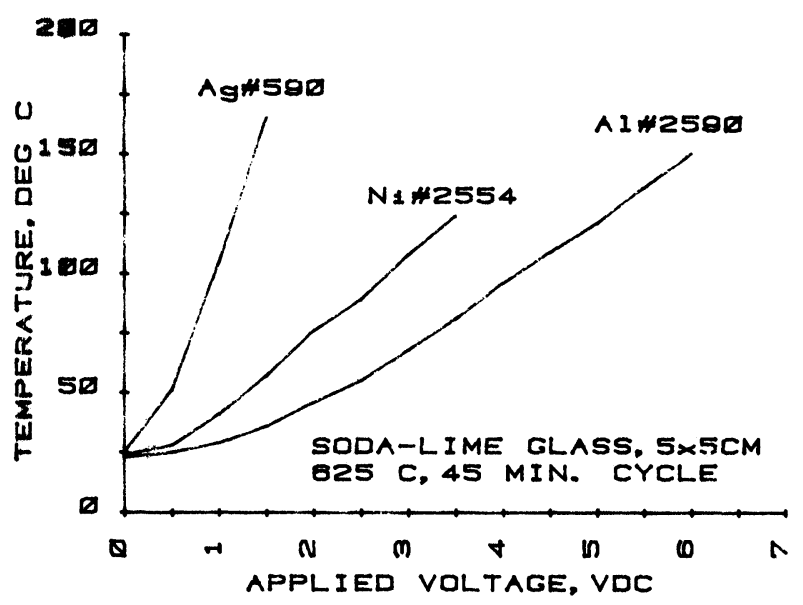

FIGURE 5 Temperature rise $v s$. applied voltage.

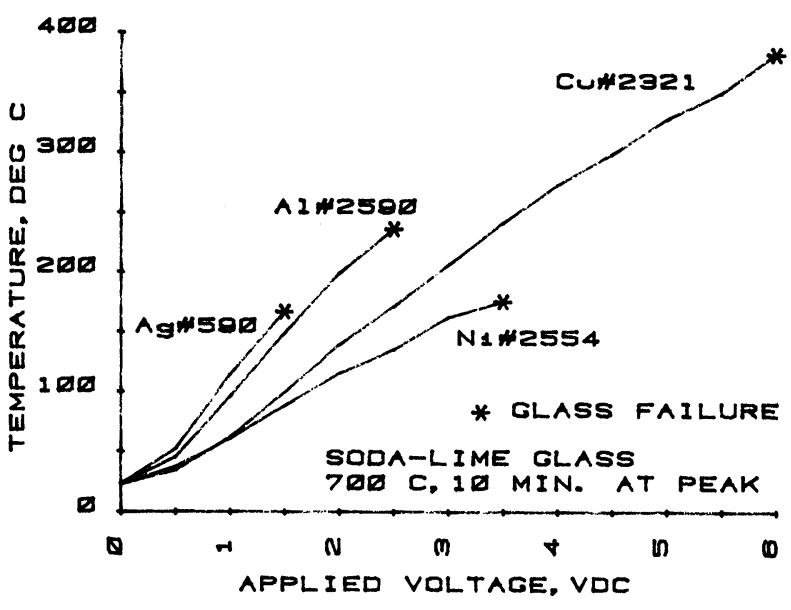

FIGURE 6 Temperature rise vs. applied voltage.

\subsection{Resistor Terminations}

The availability of a $625^{\circ} \mathrm{C}$ firing ruthenium-based resistor system, ESL \#3100 Series allowed exploration of the possibility of using air-fireable base metals. Unfortunately, $\mathrm{Al}$ and $\mathrm{Cu}$ were quickly ruled out due to the formation of non-ohmic contacts. $\mathrm{Ni}$ has received the most study. Resistivities obtained with cofired $\mathrm{Ni}$ were close to those obtained with $\mathrm{Pd} / \mathrm{Ag}$ terminations only for low resistivities. Figure 7 illustrates the negative geometry effects observed, which is more severe with the higher resistivities. This indicates that an appreciable contact resistance occurs with the nickel. This is also illustrated in Table $\mathrm{V}$ for 6 different resistivities.

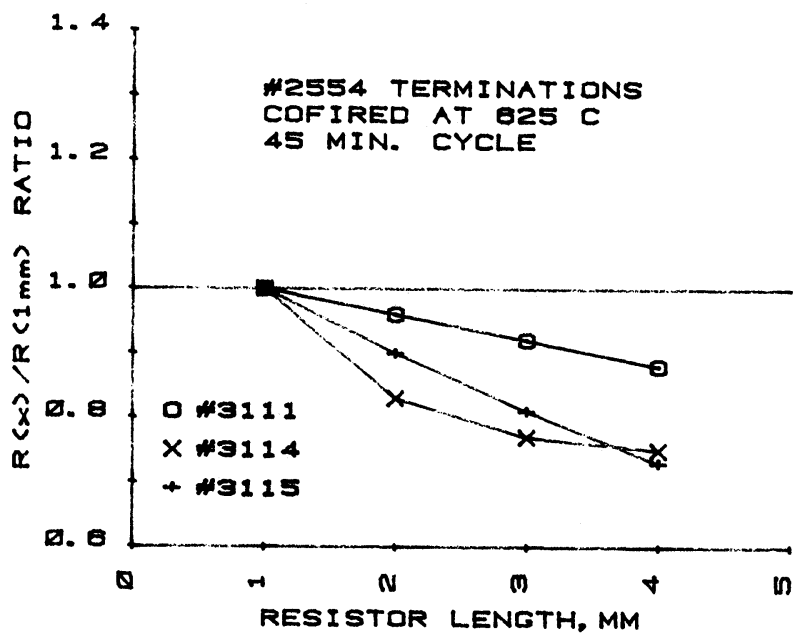

FIGURE 7 Geometry effect. 
TABLE V

\#3100 resistors with \#2554 termination. Cofired at $625^{\circ} \mathrm{C}, 45$ minute cycle $(1.25 \mathrm{~mm} \times 1.25 \mathrm{~mm}$ resistor size).

\begin{tabular}{lll}
\hline Resistor & Resistivity $(\Omega / \square)$ & TCR $\left(\mathrm{ppm} /{ }^{\circ} \mathrm{C}\right)$ \\
\hline$\# 3111$ & 9.5 & +300 \\
$\# 3112$ & 255 & +137 \\
$\# 3113$ & 5,000 & -92 \\
$\# 3114$ & 38,100 & -100 \\
$\# 3115$ & 323,000 & -184 \\
$\# 3116$ & $11,500,000$ & -273 \\
\hline
\end{tabular}

We have tried conductive terminations using $\mathrm{Ni} / \mathrm{Ag}$ and $\mathrm{Al} / \mathrm{Ag}$ compositions. Table VI presents the data for $1 \mathrm{~K} \mathrm{ohm}$ and $100 \mathrm{~K} \mathrm{ohm} /$ square pastes cofired at $625^{\circ} \mathrm{C}$. If fairly high $\mathrm{Ag}$ concentrations are used, resistor properties of the $1 \mathrm{~K} \mathrm{ohm} /$ square become comparable to the $\mathrm{Pd} / \mathrm{Ag}$ control. For the $100 \mathrm{~K}$ ohm/square, some higher resistivities and more negative TCR's are still obtained.

With $\mathrm{Ni}$ or $\mathrm{Al}$ concentrations of 50 or greater weight percentages, non-ohmic chararacter develops rapidly and resistor properties show drastic shifts from standard. On the other hand, when $60 \%$ or more of $\mathrm{Ag}$ is present, reasonably good resistor characteristics are expected in the tests under way. Heat stabilities after baking at $150^{\circ} \mathrm{C}$ for several hundred hours are comparable to those obtained with $\mathrm{Pd} / \mathrm{Ag}$.

The combination of $\mathrm{Ag}$ with $\mathrm{Ni}$ or $\mathrm{Cr}$ does not lower their resistivities in a regular or predictable way. However, $\mathrm{Al} / \mathrm{Ag}$ blends tend to be more predictable.

A preferred method of utilizing nickel (or several of the other metals) in resistor terminations is to use intermediate contacts of $\mathrm{Pd} / \mathrm{Ag}$. The overlapping $\mathrm{Pd} / \mathrm{Ag}$ gives good ohmic contact to the resistors on one side and to the base metal on the other side. This is illustrated in Figure 8. This approach uses less precious metal than the use of mixtures as previously discussed. It has the disadvantage of requiring 2 conductor

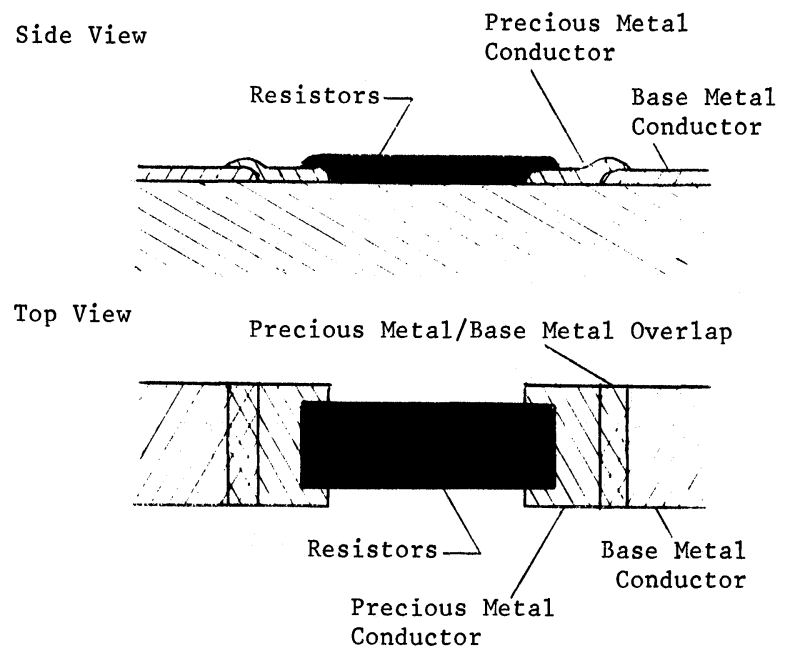

FIGURE 8 Resistor with overlapping terminations.

printings. However, the $\mathrm{Pd} / \mathrm{Ag}$ and the base metals can be cofired in most cases. Using an overlapping pad of $\mathrm{Ag}$ or $\mathrm{Pd} / \mathrm{Ag}$ is also feasible for forming solderable edge terminations (for lead attachment) and as wire bonding pads. We have also been able to print and fire gold pads on top of $\mathrm{Ni}$ and $\mathrm{Al}$ conductors. This permits eutectic IC die attachments.

Extensive experiments are planned and some are in progress aimed at studying resistor performance using overlapping base metal-Pd/Ag contacts with both $625^{\circ} \mathrm{C}$ and $850^{\circ} \mathrm{C}$ resistor systems. This is expected to be a major effort, and will be reported upon at a later date.

\subsection{Terminations for Discrete Components and Parts}

One important area of utilization of base metals is for replacing part or all of the $\mathrm{Ag}$ used in terminations of titanate capacitors, thermistors, discrete resistors,

TABLE VI

\#3100 resistors terminated with $\mathrm{Ni} / \mathrm{Ag}$ and $\mathrm{Al} / \mathrm{Ag}$. Cofired at $625^{\circ} \mathrm{C}, 45$ minute cycle.

\begin{tabular}{|c|c|c|c|c|}
\hline & \multicolumn{2}{|l|}{ \#3113 } & \multicolumn{2}{|l|}{ \#3115 } \\
\hline & Resistance $(\Omega)$ & $\mathrm{TCR}\left(\mathrm{ppm} /{ }^{\circ} \mathrm{C}\right)$ & Resistance $(\Omega)$ & $\mathrm{TCR}\left(\mathrm{ppm} /{ }^{\circ} \mathrm{C}\right)$ \\
\hline 9635B (Control) & $1.1 \mathrm{~K}$ & +85 & $91.8 \mathrm{~K}$ & -28 \\
\hline $91025 \mathrm{Ni} / \mathrm{Ag}$ & $12.8 \mathrm{~K}$ & -100 & $956 \mathrm{~K}$ & -276 \\
\hline $91050 \mathrm{Ni} / \mathrm{Ag}$ & $6.1 \mathrm{~K}$ & -119 & $439 \mathrm{~K}$ & -202 \\
\hline $91075 \mathrm{Ni} / \mathrm{Ag}$ & $1.3 \mathrm{~K}$ & +80 & $161 \mathrm{~K}$ & -100 \\
\hline $93050 \mathrm{Al} / \mathrm{Ag}$ & $1.4 \mathrm{~K}$ & +92 & $256 \mathrm{~K}$ & -159 \\
\hline $93070 \mathrm{Al} / \mathrm{Ag}$ & $1.3 \mathrm{~K}$ & +81 & $216 \mathrm{~K}$ & -118 \\
\hline $93080 \mathrm{Al} / \mathrm{Ag}$ & $1.1 \mathrm{~K}$ & +92 & $194 K$ & -128 \\
\hline
\end{tabular}


TABLE VII

Disc capacitor ${ }^{\mathrm{a}}$ termination use. Fired at $625^{\circ} \mathrm{C}$, 45 minute cycle.

\begin{tabular}{lrl}
\hline & C (pf) & D.F. (\%) \\
\hline Control, (\#9901 Ag) & 26,600 & 2.1 \\
$\# 2554(\mathrm{Ni})$ & 25,730 & 5.1 \\
$\# 2590(\mathrm{Al})$ & 8,050 & 4.4 \\
$\# 2560(\mathrm{Cr})$ & 29,700 & 2.2 \\
$\# 2554(\mathrm{Ni})$ & 26,200 & 7.8 \\
(fired at $\left.780^{\circ} \mathrm{C}\right)$ & & \\
\hline
\end{tabular}

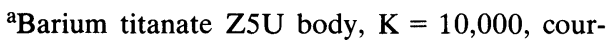
tesy of Sprague Electric Company.

varistors, etc. In addition, metallization of glass and ceramic packages, seal rings, and other structural parts is of great interest. Many of these devices could be made with one or the other of the base metals, depending on the application.

Barium titanate capacitor bodies were terminated with $\mathrm{Ni}, \mathrm{Cr}$ and $\mathrm{Al}$ on both sides of the discs. Firing was $625^{\circ} \mathrm{C}$ (45 minute cycle) and compared to a silver paste. Table VII lists the results obtained. The $\mathrm{Cr}$ and $\mathrm{Ni}$ gave capacitance values of the same order of magnitude as the $\mathrm{Ag}$. The dissipation factor of the $\mathrm{Cr}$ terminated sample was better than that of the $\mathrm{Ni}$ sample. The ceramic used was a Sprague Z5U body with a $\mathrm{K}$ of 10,000 . The Ni sample was also fired at $780^{\circ} \mathrm{C}$. This caused the capacitance to remain the same, while the dissipation factor increased significantly. However, in experiments with a different titanate composition, there was a reversal in characteristics, and the Ni gave closer agreement than $\mathrm{Cr}$ did as compared to the $\mathrm{Ag}$ controls. It should be noted that the $\mathrm{Al}$ terminations caused very low capacitance values and did not show promise for this use.

Some work with zinc oxide varistors showed promising termination results with $\mathrm{Al}$ and $\mathrm{Al} / \mathrm{Ag}$ compositions, The $\mathrm{Cr}$ and $\mathrm{Ni}$, on the other hand, showed no merit with these varistors. A number of individually optimized frit formulations may be required to match the different varistor, thermistor and capacitor bodies in commercial use.

\section{CONCLUSIONS}

Several very promising base metal compositions offer opportunities for substantial cost savings in thick film applications. Some portion of the material cost savings is negated by the need to utilize an additional printing or electroless plating step. Available high speed printing and drying equipment permit such additional expenses to be minimized. Great care must be exercised in avoiding use-conditions that may affect reliability and stability. For these requirements, overglazes may be used. It must also be recognized that simple one-to-one substitution of $\mathrm{Ag}$, $\mathrm{Au}$, etc., is not recommended. Much more work is necessary before broad utilization of these air-fireable base metal conductors can be accomplished. However, the economic pressures of high prices and potential future shortages of some of the precious metals make it imperative to explore all alternatives. 

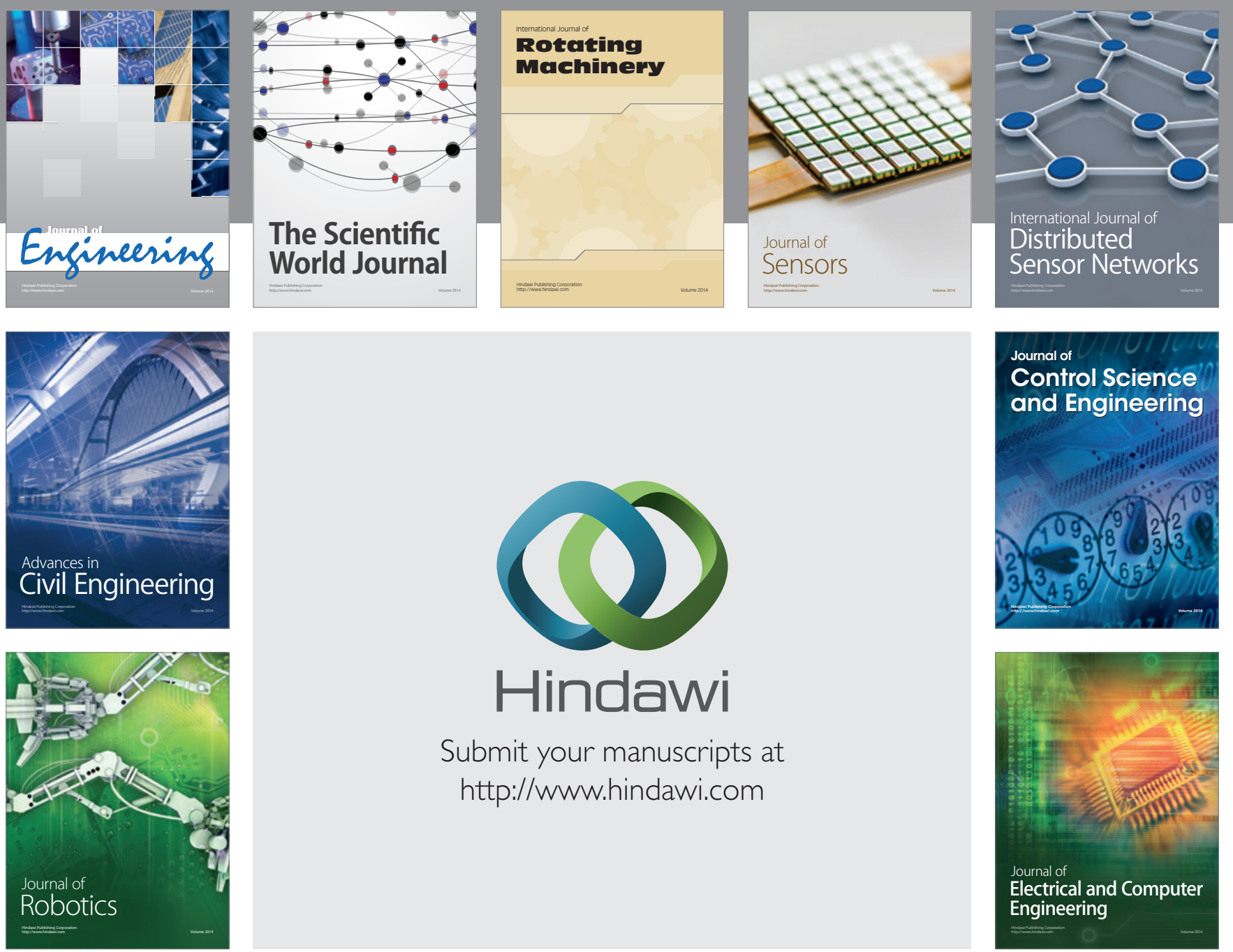

Submit your manuscripts at

http://www.hindawi.com
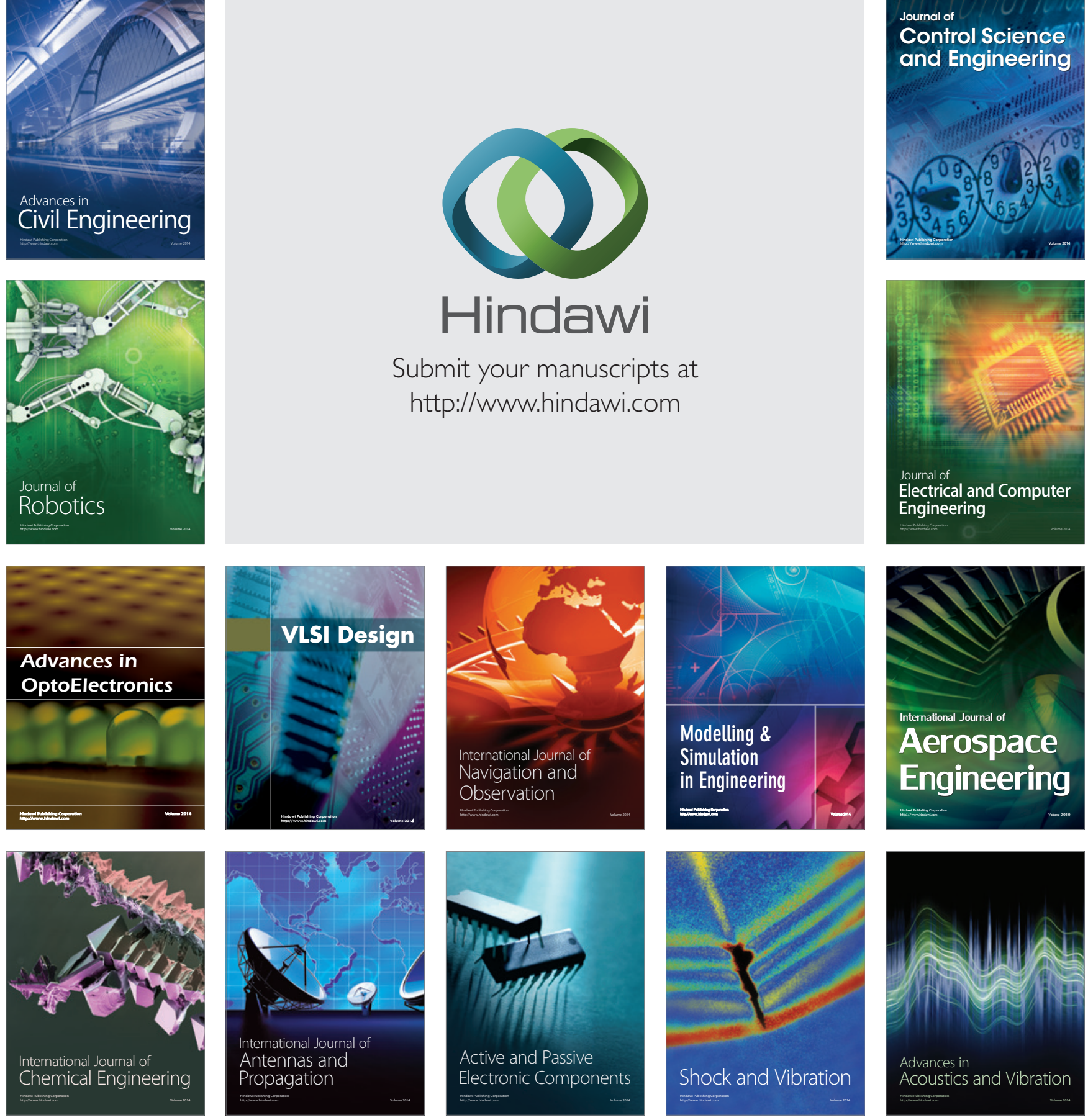